\title{
In House Training Asuhan Keperawatan Jiwa Khusus Anak dan Remaja Meningkatkan Keoptimalan Pelaksanaan Asuhan Keperawatan Jiwa Khusus Anak dan Remaja di Ruang S RS X Bogor
}

\author{
Ahmad Rizal', Lannasari ${ }^{2}$, Marisca Agustina ${ }^{3}$ \\ Departement : Jl.Harapan $50 \mathrm{Gd} . \mathrm{HZ}$ Lenteng Agung \\ (STIKes Indonesia Maju, Departemen Keperawatan, Indonesia) \\ Email : rizal@stikim.ac.id
}

Artikel Info

Ciptaan disebarluaskan di bawah Lisensi Creative

Commons Atribusi-

BerbagiSerupa 4.0

Internasional.

Kata Kunci : SBAR, timbang terima, perawat
Abstrak

Latar Belakang: Hasil pengkajian mengidentifikasi adanya optimalnya pelaksanaan asuhan keperawatan jiwa khusus anak dan remaja. Tujuan: penelitian ini bertujuan untuk mengidentifikasi akar penyebab masalah yang ditemukan dan menemukan inovasi sebagai landasan perubahan dalam area rumah sakit. Metode: Penulis menggunakan metode studi kasus. Hasil: SPK \& RKK perawat yang ada tidak tertera kompetensi khusus asuhan keperawatan jiwa anak dan remaja dan Sebagian besar belum pernah mengikuti pelatihan asuhan keperawatn jiwa khusus jiwa anak dan remaja. sehingga menyebabkan kurang optimalnya pelaksanaan asuhan keperawatan jiwa khusus anak dan remaja Kesimpulan: Pelaksanaan In House Training Asuhan Keperawatan Jiwa Khusus Anak dan Remaja dengan monitoring dan evaluasi berkala dapat meningkatkan keoptimalan pelaksanaan asuhan keperawatan jiwa khusus anak dan remaja.

\section{Pendahuluan}

Rumah sakit tempat pemberi layanan kesehatan yang harus memberikan pelayanan unggul dan paripurna. Peran Rumah Sakit dalam mewujudkan masyarakat sehat, menempati bagian yang sangat penting yaitu: promotif, preventif, kuratif dan rehabilitatif. Selain sarana prasarana, pegawai merupakan faktor penting, perawat merupakan bagian yang tidak terpisahkan di rumah sakit. ${ }^{1}$ Unit rawat inap sebagai salah satu fasilitas dari pelayanan kesehatan di Rumah Sakit harus dapat memberikan pelayanan keperawatan yang komprehensif, berkualitas, safety dan berfokus pada pasien. Untuk dapat memberikan pelayanan keperawatan yang berkualitas diperlukan pengelolaan yang baik terhadap sumber daya yang ada di unit rawat inap dengan menggunakan prinsip manajemen. Manajemen pelayanan rawat inap bagi kepala ruang/unit di rumah sakit merupakan rangkaian kegiatan yang dilaksanakan secara sistematik di unit rawat inap meliputi perencanaan, penggerakan, pelaksanaan serta pengendalian, pengawasan dan penilaian untuk memberikan pelayanan keperawatan yang bermutu di unit rawat inap. ${ }^{1}$

Mutu pelayanan keperawatan merupakan cerminan mutu pelayanan kesehatan. Mutu adalah tingkat layanan kesehatan yang konsisten dengan pengetahuan profesional yang diperbarui dan memungkinkan diperolehnya hasil yang diinginkan. ${ }^{2}$ Perawat sebagai salah satu profesi yang berperan penting dalam penyelenggaraan mutu pelayanan kesehatan di rumah sakit. Pelayanan keperawatan di rumah sakit merupakan bagian dari integral dari pelayanan kesehatan yang mempunyai konstribusi yang sangat menentukan kualitas pelayanan rumah sakit. Sehingga setiap upaya untuk peningkatan pelayanan rumah sakit juga diikuti upaya 
peningkatan profesionalitas dan kualitas pelayanan keperawatan. Kinerja mutu dan manfaat pelayanan keperawatan menggambarkan kinerja pelayanan keperawatan. Adapun kinerja yang dapat dilaporkan dari program kerja keperawatan yaitu : indikator klinik mutu pelayanan keperawatan, hasil evaluasi standar asuhan keperawatan, efektivitas pengembangan SDM, evaluasi efisiensi dan manfaat pelayanan. ${ }^{3}$ Praktik manajemen keperawatan dalam lingkup manajemen diharapakan dapat memberikan kontribusi dalam memecahkan masalah yang bersifat teknis operasional dari aspek manajemen keperawatan tertentu melalui beberapa alternatif penyelesaian masalah sehingga mutu pelayanan keperawatan meningkat dan pada akhirnya dapat meningkatkan mutu pelayanan kesehatan, penelitian ini bertujuan untuk mengidentifikasi akar penyebab masalah yang ditemukan dan menemukan inovasi sebagai landasan perubahan dalam area rumah sakit.

\section{Metode}

Studi kasus dilakukan untuk menganalisis pelaksanaan timbang terima di RS S. Pengumpulan data dilakukan dengan menelaah dokumen, wawancara, dan kuesioner yang disebarkan kepada tenaga keperawatan yang telah bekerja lebih dari tiga tahun di ruangan S RS $S$ Bogor, dan kepada kepala ruangan juga ketua tim yang bekerja di ruangan tersebut. Analisis situasi dilakukan dengan analisis tulang ikan/fish bone dengan tujuan mengidentifikasi factorfaktor penyebab ketidakoptimalan pelaksanaan Asuhan Keperawatan Jiwa Khusus Anak dan Remaja, kemudian dibuat rencana tindakan bersama dengan kepala ruangan, ketua tim dan perawat pelaksana berdasarkan permasalahan yang ada. Analisis didasarkan pada peran dan fungsi manajemen keperawatan.

\section{Hasil}

Ruangan S merupakan salah satu ruangan rawat inap RS X. Ruangan ini merawat pasien gangguan jiwa khusus anak dan remaja dalam fase stabilisasi dengan kapasitas tempat tidur yaitu 18 TT baik laki - laki maupun perempuan yang dipisahkan sayap kiri dan kanan. Berikut denah ruangan S RS X Bogor.

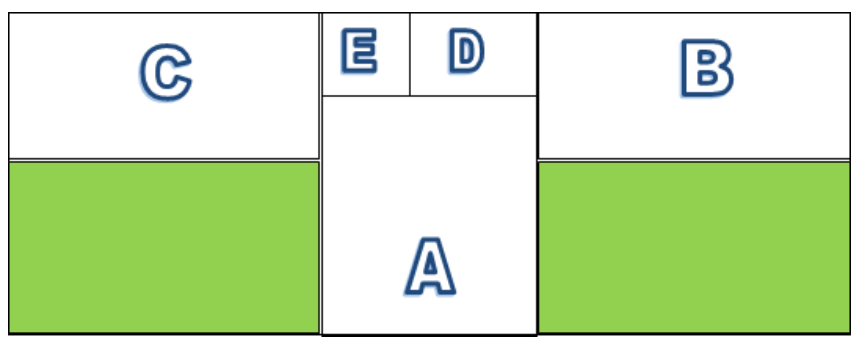

Gambar 1. Denah Ruangan

Keterangan:

A : Nurse Station, Ruang Makan Dan Rekreasi Musik/Nonton TV

B : Kamar Perawatan Perempuan

C : Kamar Perawatan Laki - laki

D : Ruangan Konseling

E : Ruangan Seklusi

Ruangan S RS X Bogor terdiri dari direktur utama dan direktur medis dan keperawatan pada tingkat top manager, kepala instalasi rawat inap pada tingkat middle manager, dan kepala ruangan pada tingkat low manager. Berikut struktur organisasi Ruang S RS X Bogor. 


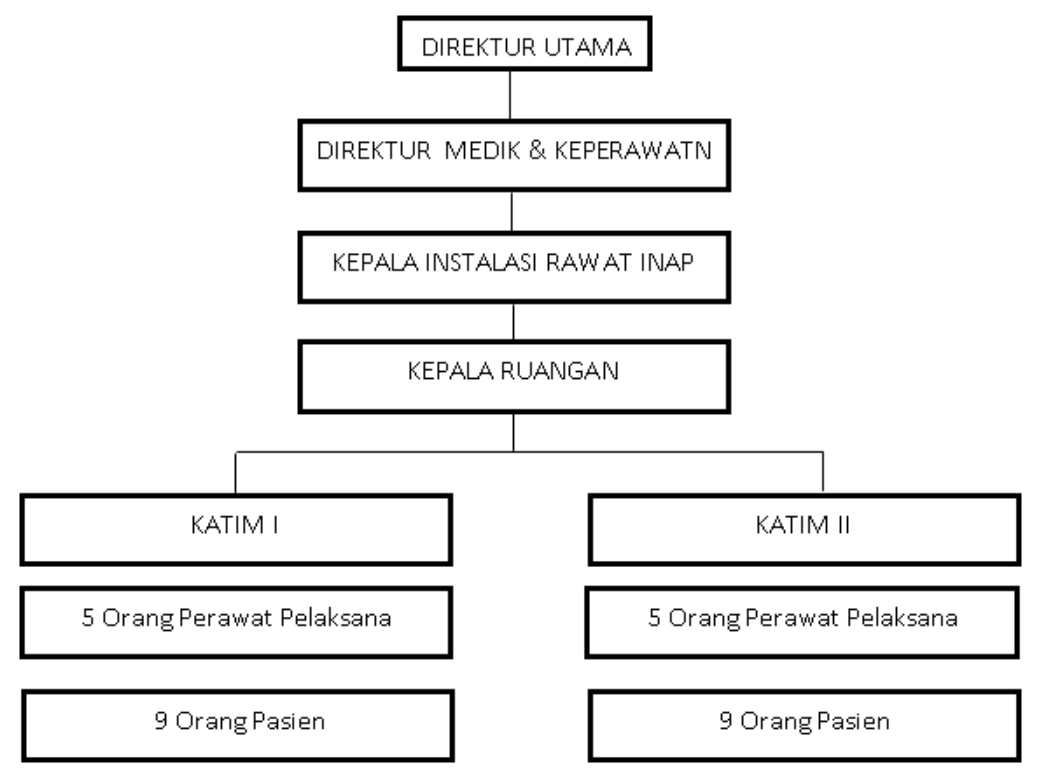

Gambar 2. Susunan Manajemen Organisasi RS

Jumlah tenaga keperawatan di ruangan $S$ sebanyak 13 orang, dengan formasi jabatan satu orang sebagau kepala ruangan, dua orang sebagai ketua tim, dan sepuluh orang sebagai perawat pelaksana.

Tabel 1. Presentase Jabatan Ruangan

\begin{tabular}{lll}
\hline Jabatan & Jumlah & Prosentase \\
\hline Kepala Ruangan & 1 & $7,69 \%$ \\
\hline Ketua Tim & 2 & $15,38 \%$ \\
\hline Perawat Pelaksana & 10 & $76,93 \%$ \\
\hline Total & $\mathbf{1 3}$ & $\mathbf{1 0 0 \%}$ \\
\hline
\end{tabular}

Jumlah tenaga keperawatan ruang S sebanyak 13 orang, dengan total jumlah perawat dengan Pendidikan terakhir Ners adalah satu orang, diikuti jumlah perawat dengan Pendidikan terakhir D3 adalah sebanyak 12 orang.

Tabel 2. Presentase berdasarkan Pendidikan

\begin{tabular}{lll}
\hline Jabatan & Jumlah & Prosentase \\
\hline Ners & 1 & $7,69 \%$ \\
\hline D3 Keperawatan & 12 & $92,31 \%$ \\
\hline Total & $\mathbf{1 3}$ & $\mathbf{1 0 0 \%}$ \\
\hline
\end{tabular}

Berdasarkan perhitungan ketenagaan dapat disimpulkan bahwa jumlah perawat 13 orang sudah cukup. Namun demikian karena pandemi COVID 19 sering terjadi relokasi tenaga yagn dimana 2 orang ditugaskan di raungan khusus perawatan COVID. Hal ini tentu saja menjadi tantangan bagi manajemen di ruangan terkait jadwal dinas. Kepala ruangan bersama katim menyusun jadwal seoptimal mungkin dengan SDM yang ada. Hasil wawancara yang didapatkan dari kepala ruangan menyatakan bahwa pelaksanaan asuhan keperawatan khusus jiwa anak dan remaja yang dilakukan oleh stafnya secara pendekatan usia dan karakteristik anak belum optimal dilakukan oleh semua perawat dikarenakan ha staf keperaya 3 dari 13 orang perawat di ruangan yang sudah mengikuti pelatihan asuhan keperawatan jiwa khusus anak dan remaja. Selain itu tidak diangkatnya masalah keperawatan yang mengarah kepada masalah tumbuh kembang 
anak. Ketua tim mengatakan pelaksanaan pre \& post conference dilakukan ketika syarat personil saat dinas pagi mencukupi. bila tidak mencukupi maka kegiatan ini tidak dilakukan. Hasil observasi di ruangan menyatakan mengidentifkasi terkait SPK \& RKK perawat yang ada tidak tertera kompetensi khusus asuhan keperawatan jiwa anak dan remaja. Sistem pendokumentasian masih manual (menulis di form). Perawat yang dinas pagi hanya 2 katim dan 1 perawat pelaksana sehingga tidak dilakukan pre dan post conference. Dari hasil kuosioner, 10 dari 13 orang belum pernah mengikuti pelatihan asuhan keperawatn jiwa khusus jiwa anak dan remaja. Masalah yang diambil mengerucut menjadi dua, yakni belum optimalnya pelaksanaan asuhan keperawatan jiwa khusus anak dan remaja; dan Belum optimalnya pelaksanaan pre dan post conference. Berikut fish bone yang digambarkan untuk mendeskripsikan masalah dan akar akar penyebab masalah yang menimbulkannya.

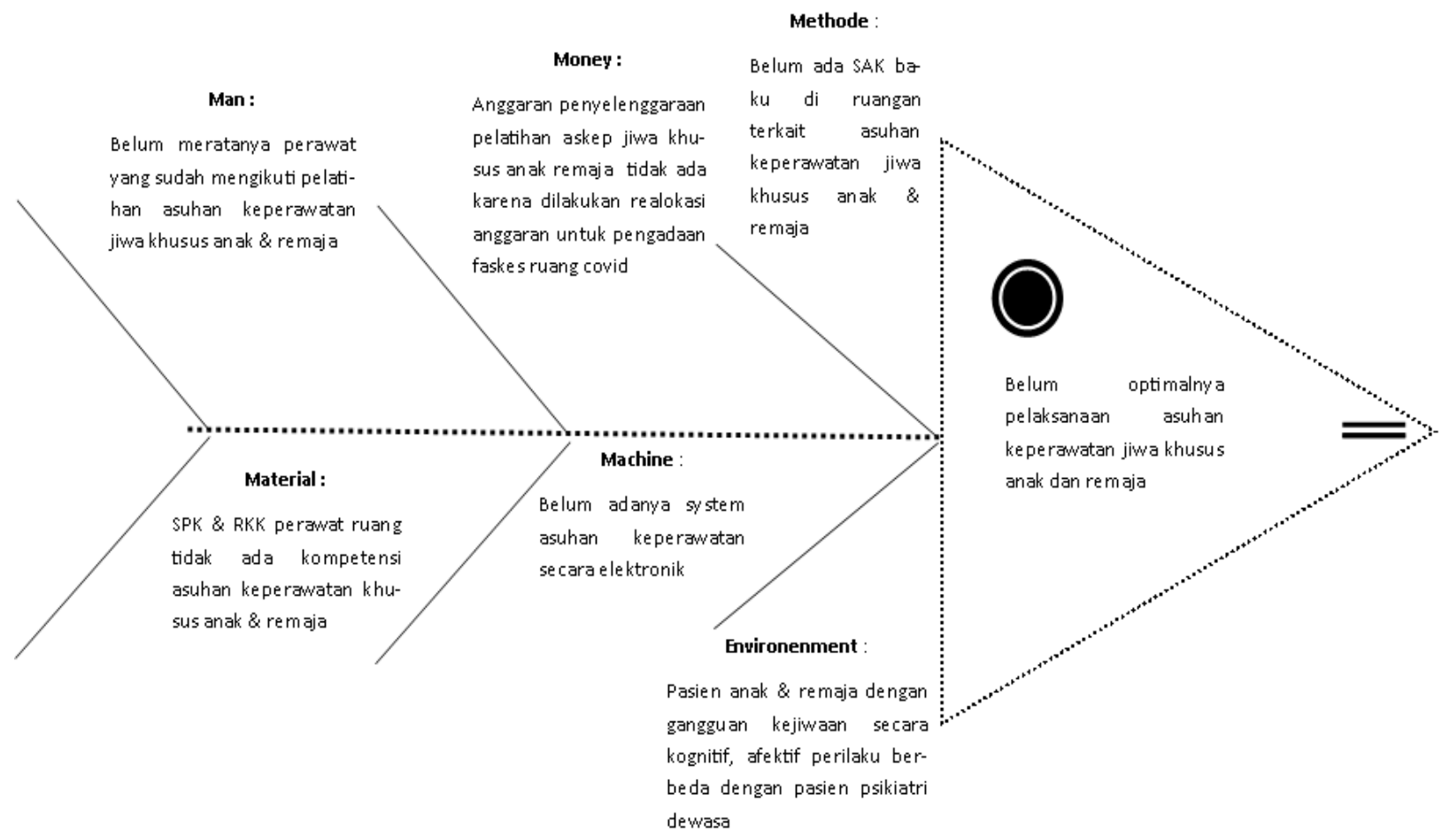

Gambar 3. Fishbone

Permasalahan yang berhasil diidentifikasi, dipertimbangkan berdasarkan waktu, keterbatasan sumber daya, dan kewenangan atau kemampuan mengatasi masalah yang ada, sehingg a masalah yang akan diatasi adalah maslaah yang termasuk prioritas utama. Hasil identifikasi data di ruangan ditemukan beberapa masalah yang timbul, sehingga penulis membuat table prioritas masalah untuk menentukan masalah yang terlebih dahulu harus diselesaikan. Proses melakukan prioritas masalah dilakukan dengan mempehatikan aspek kecenderungan besar dan seringnya masalah tersebut, besarnya kerugian yang ditimbulkan dari masalah, bisa dipecahkan, melibatkan pertimbangan dan perhatian perawat, dan ketersediaan sumber daya. Berikut adalah table penentuan prioritas maslaah yang ditemukan. Hasil perhitungan table seleksi alternatif masalah yang menjadi prioritas adalah In House Training Asuhan Keperawatan Jiwa Khusus Anak \& Remaja, sehingga dibuat plan of action untuk rencana penyelesaian masalah. 
Tabel 3. Planning of Action

\begin{tabular}{|c|c|c|c|c|c|c|}
\hline No & Kegiatan & Tujuan & Metode & Sasaran & Waktu/tempat & PJ \\
\hline 1. & $\begin{array}{lr}\text { In } & \text { House } \\
\text { Training } & \text { Askep } \\
\text { Jiwa } & \text { Khusus } \\
\text { Anak \& } & \text { Remaja }\end{array}$ & $\begin{array}{l}\text { Meningkatkan pengetahuan } \\
\text { dan keterampilan perawat } \\
\text { dalam melaksanakan askep } \\
\text { jiwa khusus anak \& remaja }\end{array}$ & $\begin{array}{l}\text { Ceramah } \\
\text { Tanya jawab }\end{array}$ & $\begin{array}{l}\text { Perawat ruang } \\
\mathrm{S}\end{array}$ & $\begin{array}{l}\text { Jum'at, } 2 \text { Juli } \\
2021 \\
\text { Pkl 13.00-15.00 } \\
\text { WIB } \\
\begin{array}{l}\text { Aplikasi zoom } \\
\text { meeting }\end{array}\end{array}$ & $\begin{array}{l}\text { Mahas } \\
\text { iswa }\end{array}$ \\
\hline 2. & $\begin{array}{l}\text { Rekomendasi } \\
\text { penyusunan } \\
\text { SAK baku } \\
\text { asuhan } \\
\text { keperawatan } \\
\text { jiwa khusu anak } \\
\text { \& remaja }\end{array}$ & $\begin{array}{ll}\text { Adanya pedoman baku } \\
\text { asuhan keperawatan } & \text { jiwa } \\
\text { khusus anak \& remaja } & \end{array}$ & $\begin{array}{l}\text { Diskusi } \\
\text { Negosiasi }\end{array}$ & $\begin{array}{l}\text { Komite } \\
\text { Keperawatan }\end{array}$ & $\begin{array}{l}\text { Jum'at, } 2 \text { Juli } \\
2021 \\
\text { Paska } \\
\text { Pelaksanaan In } \\
\text { House Training }\end{array}$ & $\begin{array}{l}\text { Mahas } \\
\text { iswa }\end{array}$ \\
\hline 3 & $\begin{array}{l}\text { Rekomendasi } \\
\text { pelatihan asuhan } \\
\text { jiwa khusus } \\
\text { anak remaja } \\
\text { terintegrasi } \\
\text { multi profesi }\end{array}$ & $\begin{array}{l}\text { Meningkatnya pengetahuan } \\
\text { dan keterampilan serta } \\
\text { koordinasi multiprofesi }\end{array}$ & $\begin{array}{l}\text { Diskusi } \\
\text { Negosiasi }\end{array}$ & $\begin{array}{l}\text { Komite dan } \\
\text { manajemen }\end{array}$ & & \\
\hline 4 & $\begin{array}{l}\text { Rekomendasi } \\
\text { pencantuman } \\
\text { kompetensi } \\
\text { khusus askep } \\
\text { anak remaja } \\
\text { pada SPK RKK } \\
\text { perawat ruang S }\end{array}$ & $\begin{array}{l}\text { Legalitas dan pengakuan } \\
\text { atas kompetensi perawat } \\
\text { ruang } \mathrm{S} \text { terkait askep jiwa } \\
\text { khusus remaja }\end{array}$ & $\begin{array}{l}\text { Diskusi } \\
\text { Negosiasi }\end{array}$ & $\begin{array}{l}\text { Komite dan } \\
\text { manajemen }\end{array}$ & & \\
\hline 5 & $\begin{array}{l}\text { Rekomendasi } \\
\text { pengadaan } \\
\text { asuhan } \\
\text { keperawatan } \\
\text { secara } \\
\text { elektronik }\end{array}$ & $\begin{array}{lr}\text { Mempermudah } & \text { perawat } \\
\text { dalam } & \text { melakukan } \\
\text { dokumentasi } & \end{array}$ & $\begin{array}{l}\text { Diskusi } \\
\text { Negosiasi }\end{array}$ & $\begin{array}{l}\text { Komite dan } \\
\text { manajemen }\end{array}$ & & \\
\hline
\end{tabular}

\section{Pembahasan}

Kualitas asuhan keperawatan dipengaruhi oleh berbagai pihak. Kualitas asuhan keperawatan dipengaruhi oleh perawat itu sendiri, pola kerja di rumah sakit, dukungan kebijakan rumah sakit, pengakuan prestasi kerja perawat. ${ }^{4}$ Dalam memberikan asuhan keperawatan, perawat berinteraksi 24 jam dengan pasien dan keluarga. dengan demikian perawat berperan penting menentukan kualitas mutu layanan di rumah sakit, perawat yang puas dengan pekerjaannya maka akan dapat menyelesaikan pekerjaan dengan baik dan membuat pasien atau keluarganya puas. ${ }^{5}$ Di ruangan $S$ berdasarkan data bahwa hanya 3 dari 13 orang yang sudah memiliki sertifikat pelatihan Asuhan Keperawatan Jiwa Khusus Anak \& Remaja, hal ini tentunya akan berdampak pada kompetensi 10 perawat ruangan tersebut yang belum pernah mengikuti pelatihan tersebut. Pada akhirnya akan berdampak pada metode pendekatan dan diagnosa spesifik anak dan remaja. Pilar IV MPKP merupakan area pelayanan klinis perawatan. Pada pilar ini perawat yang bertugas di ruangan harus mempunyai kompetensi yang sesuai dengan kebutuhan ruangan. Di lihat dari data perawat Ruang $S$ tentunya ini tidak sesuai dengan pilar IV MPKP. ${ }^{6}$

Sumber daya manusia adalah aset penting perusahaan yang memilikikemampuan berkembang sebagai penentu keberhasilan perusahaan dalam jangka panjang. Sumber daya manusia (SDM) berperan penting dalam pencapaian visi dan misi perusahaan, karenanya peningkatan ketrampilan sumber daya manusia berada di urutan tertinggi. ${ }^{7}$ Memiliki sumber daya manusia yang teruji baik berdasar kemampuan, ketrampilan, kesetiaan pada perusahaan dan bersemangat dalam mencapai tujuan perusahaan akan membuat perusahaan tetap mampu bersaing dalam era persaingan global. Untuk meningkatkan kinerja karyawan, perusahaan menempuh beberapa cara misalnya melalui pendidikan, pelatihan, pemberian motivasi yang layak, menciptakan, lingkungan kerja yang kondusif dan pemberian motivasi. ${ }^{8}$ 
Pelatihan merupakan proses meningkatkan pengetahuan dan keterampilan karyawan. ${ }^{9}$ Memperbaiki kinerja merupakan salah satu tujuan dari pelatihan. ${ }^{10}$ Salah satu tujuan yang esensial dalam pelatihan adalah mempunyai andil yang besar dalam menentukan efektivitas dan efesiensi organisasi. Pelatihan merupakan salah satu faktor yang berasal dari dukungan organisasi yang dapat mempengaruhi kinerja pegawai dalam pembagian faktor yang mempengaruhi kinerja. Distance learning berbasis teknologi merupakan salah satu upaya peningkatan pengetahuan bagi tenaga perawat, tidak hanya untuk pendidikan formal, tetapi juga sebagai pusat pelatihan, pusat konsultasi, pusat riset, dan pusat sharing komunikasi antar perawat. Distance learning atau lebih umum disebut elearning merupakan salah satu metode pembelajaran pelatihan berbasis teknologi informasi, sangat sesuai dengan era teknologi informasi saat ini. ${ }^{11}$ Apalagi di masa pandemi COVID 19 ini pembelajaran secara daring menjadi hal yang lazim dilakukan.

\section{Kesimpulan}

Manajemen keperawatan dapat didefinisikan sebagai suatu proses dari perencanaan, pengorganisasian, ketenagaan, pengarahan, dan pengendalian untuk mencapai tujuan. Berdasarkan pada tujuan penelitian maka kami mengambil kesimpulan bahwa penerapan peran kepala ruangan dalam pelaksanaan fungsi manajemen keperawatan berdasarkan prioritas masalah, yaitu belum adanya draft/SPO asuhan keperawatan berdasarkan standar 3S (SDKI, SLKI, SIKI) PPNI di ruang rawat inap Ruangan $\mathrm{R}$ sudah optimal, seperti implementasi dan evaluasi desiminasi refresh ilmu, diskusi dan sosialisasi tentang proses pendokumentasian asuhan keperawatan berdasarkan standar 3S (SDKI, SLKI, SIKI) PPNI sudah dilakukan namun pada prakteknya kegiatan proses pendokumentasian keperawatan di atas tidaklah selalu berurutan akan tetapi dikerjakan pada waktu bersamaan/tumpang tindih (overlapping). Oleh karena itu perlu dilakukan supervisi oleh kepala ruangan secara berkala dan berkelanjutan berdasarkan SPO supervisi yang telah disahkan sedangkan untuk hasil dari pengajuan usulan draft asuhan keperawatan berdasarkan standar 3S (SDKI, SLKI, SIKI) PPNI masih dalam proses pembahasan namun kami telah memberikan buku panduan $3 S$ untuk melatih dan menerapkan asuhan keperawatan menggunakan ketiga buku tersebut sebelum draft asuhan keperawatan dibuat oleh tim kelompok kerja (pokja) draft dokumen asuhan keperawatan.Pelaksanaan patient safety, khususnya pencegahan risiko cedera akibat jatuh karena minimnya gambar atau stiker risiko jatuh sudah kami lakukan dengan cara menempel stiker di area tempat tidur pasien selain pemakaian gelang risiko yang sudah bagian dari standar pelayanan rumah sakit meskipun kegiatan ini bukan termasuk prioritas masalah.

\section{Deklarasi Konflik Kepentingan}

menyatakan bahwa penelitian ini independen dari konflik kepentingan individu dan organisasi.

\section{Ucapan Terimakasih}

Terimakasih kepada tim manajemen dan RS yang telah membantu proses penelitian ini

\section{Referensi}

1. Karimah, Iffah. Perbandingan Tingkat Kepuasan Kerja Perawat Rumah Sakit Pemerintah dan Rumah Sakit Swasta di Kota Makassar. Diss. Universitas Islam Negeri Alauddin Makassar, 2017.

2. Mudallal, Rola H., et al. "Quality of nursing care: the influence of work conditions and burnout." International Journal of Africa Nursing Sciences 7 (2017): 24-30.

3. Chandra, Syah Putra. "Buku Ajar Manajemen Keperawatan, teori dan Aplikasi Praktek dilengkapi dengan Kuesioner pengkajian praktik Keperawatan." (2014).

4. Marquis, Bessie L., and Carol Jorgensen Huston. Leadership roles and management functions in nursing: Theory and application. Lippincott Williams \& Wilkins, 2009.

5. Bustami, M. S. "Penjaminan mutu pelayanan kesehatan \& akseptabilitasnya." (2011).

6. Pratiwi, Arum, and Abi Muhlisin. "Kajian Penerapan Model Praktik Keperawatan Profesional (MPKP) Dalam Pemberian Asuhan Keperawatan di Rumah Sakit." (2008).

7. Istijanto, M. M. Riset sumber daya manusia. Gramedia Pustaka Utama, 2013.

8. Tawale, Efa Novita, Widjajaning Budi, and Gartinia Nurcholis. "Hubungan antara motivasi kerja perawat dengan kecenderungan mengalami burnout pada perawat di RSUD Serui-Papua." Jurnal Insan 13.2 (2011): 74-84. 
9. Lestari, Putu Ayu, and Anak Agung Ayu Sriathi. Pengaruh Pelatihan Kerja, Lingkungan Kerja Fisik serta Motivasi terhadap Produktivitas Kerja Pegawai Pada PT. Taspen (Persero) Kantor Cabang Denpasar. Diss. Udayana University, 2013.

10. Elizar, Elizar, and Hasrudy Tanjung. "Pengaruh Pelatihan, Kompetensi, Lingkungan Kerja terhadap Kinerja Pegawai." Maneggio: Jurnal IImiah Magister Manajemen 1.1 (2018): 46-58.

11. Darmayanti, Tri, Made Yudhi Setiani, and Boedhi Oetojo. "E-learning pada pendidikan jarak jauh: konsep yang mengubah metode pembelajaran di perguruan tinggi di Indonesia." Jurnal Pendidikan Terbuka dan Jarak Jauh 8.2 (2007): 99-113. 